Варданян Марина, доктор філологічних наук, доцент, декан факультету іноземних мов Криворізький державний педагогічний університет

\title{
ПЕРЕКЛАДАЦЬКА ДІЯЛЬНІСТЬ УКРАЇНСЬКОЇ ДІАСПОРИ ХХ СТОЛІТТЯ: НАПРЯМИ ТА ЗДОБУТКИ
}

\begin{abstract}
У статті визначаються три головні напрямки перекладацъкоӥ діяльності украӥнсъкоӥ діаспори. Периий напрямок сягає власне бормування перекладащтва в украӥнсъкому зарубіжжі, що пов'язано з історією перекладу. Оскілъки перекладачі українсъкого зарубіжюя зазвичай були переважно теоретиками та критиками художнъого перекладу, другий напрямок перекладацъкой діялъності розкриває питання теоретичних аспектів перекладу (питання перекладу поезій, вивчення принципів укладання перекладних антологій, жанрів перекладу тощо). Третій напрямок охоплюе власне мистецькі практики перекладачів украӥнсъкого зарубіжсж, постаті яких узагальнюються за різними критеріями.
\end{abstract}

Ключові слова: перекладачі, украӥнсъка діаспора, художній переклад.

Vardanian M. The Ukrainian Diaspora's translating activities of the 20th century: directions and achievements.

The article deals with the Ukrainian translating activities having taken place abroad in the 20th century. The issue has not been studied in details yet. The researchers such as I. Dziuba, M. Inytskyi, S. Pavlychko, and etc. focused their attention on some of the most presentable figures, including Ihor Kachurovskyi, Ihor Kostetskyi, and representatives of "the New York Group". Therefore, the goal of the article is to identify and characterize the directions and achievements of the translating activities of the Ukrainian Diaspora of the twentieth century.

The article identifies three main directions of the Ukrainian Diaspora's translation activity. The development of translation in Ukrainian abroad community is the first direction of this activity. This aspect is connected with the history of translation. I argue that such Ukrainian Diasporic artistic associations as "MUR" and "Slovo" actively developed Ukrainian translation studies abroad. The main achievement of the first association is the understanding of translation as a necessary component for the promotion of the Ukrainian language and culture. However, the main achievement of the second association was edition in different languages of the translations of Ukrainian writings. These translations greatly enriched the theory and practice of artistic translation.

As Ukrainian Diasporic translators were usually theorists and critics of artistic translation, the second area of translation activity raises the 
theoretical issues of translation (such as translation of poetry, study of the principles of translating anthologies, genres of translation, etc.). B. Kravtsiv, B. Lepkyi, I. Kostetskyi, I. Kachurovskyi, etc. studied these issues in their researches.

The third area covers the actual artistic practices of Ukrainian Diaspora's translators, whose figures are generalized on the basis of different criteria. In my opinion, the chronology criteria or the criteria of belonging to a translation school / generation can be interesting for researchers of Ukrainian translation history, because both help trace the evolution of Ukrainian translating activities abroad.

Key words: translators, Ukrainian Diaspora, artistic translation.

Постановка проблеми. Перекладацька діяльність української діаспори XX століття - цікаве, але малодосліджене явище як в українському літературознавстві, так і перекладознавстві. Його осмислення перебуває на прикордонні різних наук, що пов'язані 3 розв'язанням конкретних задач - від вивчення історичного розвитку художніх творів, осмислення літературних понять до реалізації перекладацьких трансформацій, культурних кодів та патернів.

Перефразовуючи думку авторів колективної праці «Зарубіжні українці», украӥнсъка діаспора не лище здійснила вагомий вклад у загальний розвиток культури, науки, мистецтва, літератури як украӥнсъкого народу, так $і$ народів свого поселення; вона також стала джерелом знань про Україну у світі [3, с. 3]. Тож для української діаспори переклад виконував подвійну функцію: презентувати українському читачу найкращий світовий досвід; популяризувати українську мову, літературу та культуру за межами України, у місцях проживання українців зарубіжжя. Такі наміри української інтелігенції реалізували одну з функцій перекладу, а саме: розгортання діалогу культур, або іншими словами - бути засобом міжкультурної комунікації.

Аналіз останніх досліджень і публікацій з теми. Сучасні вітчизняні дослідження характеризуються пожвавленням наукового інтересу навколо питань як зарубіжного українознавства, так i перекладознавства. Проте обрана нами тема представлена спорадично, переважно через осмислення окремих постатей українських діаспорних перекладачів, серед яких найбільш презентабельні Ігор Качуровський, Ігор Костецький та представники «нью-йоркської групи». До таких досліджень можна віднести розвідки І. Дзюби «Вірність собі» про Ігоря Качуровського [2], М. Ільницького «Мале літературне відродження: літературна критика періоду МУРу» щодо поглядів І. Костецького про першотвір [4], а також два розділи 
3 монографії С. Павличко «Теорія літератури» [12] тощо, у якій дослідниця розглядає перекладацтво української еміграції часів МУРу та «Слова» як модерністські практики. Тож цілий пласт перекладацької літератури української діаспори XX століття ще чекає на своїх дослідників. У цьому процесі вважається за доцільне насамперед систематизувати та узагальнити матеріали з цієї теми, що доступні українським дослідникам.

Формування мети статті. Слід наголосити, що власне перекладацька діяльність української діаспори XX століття стала предметом осмислення у працях переважно самих представників того зарубіжжя. Саме такі матеріали становлять фактичний матеріал для цієї розвідки. Головною метою статті є визначити та охарактеризувати основні напрями й здобутки перекладацької діяльності української діаспори ХХ століття.

Виклад основного матеріалу дослідження. Перекладацьку діяльність української діаспори XX століття, на наш погляд, можна осмислювати в кількох напрямках, яких у цій статті визначаємо три, що пов'язані з історією перекладу, літературними питаннями перекладу, його поняттями та перекладацькими практиками української діаспори $\mathrm{XX}$ століття.

Перииц напрямок сягає власне формування перекладацтва в українському зарубіжжі. У цьому плані найбільш загальне уявлення про становлення перекладної літератури в Україні та за їі межами дає розгорнута стаття діаспорних дослідників Б. Кравціва та А. Жуковського в «Енциклопедії українознавства», що має таку хронологію: «княжа доба», XVIII, XIX та XX століття (зокрема, періоди 1918-1939 pр. та з 1945 р.) [7]. У цій класифікації останній етап, ХX століття, автори прагнуть подати як цілісне явище українського перекладацтва, тому звертаються до постатей перекладачів як в еміграції, так і на території материкової України.

Характеристику основним етапам українського перекладацтва дав I. Качуровський у своїй радіобесіді «Максим Рильський як перекладач», де визначив три його періоди [6, с. 12]: перший етап (XIX ст.), пов'язаний із травестовими перекладами П. Гулака-Артемовського, нострифікованого переспіву М. Писаревської, перекладами П. Куліша; серед представників другого етапу названо I. Франка, Лесю Українку, Миколу Вороного та ін.; а третій етап, що почався з 20-х років ХХ століття, асоціюється з творчістю «київських неокласиків».

Власне активне формування перекладознавства українського зарубіжжя відбувалося завдяки літературними угрупуваннями МУР 
та «Слово», які не лише включали до свого складу письменників, поетів, драматургів чи літературних критиків. Дуже часто саме ці митці були і перекладачами.

Здобуткам української діаспори на ниві художнього перекладу присвячена низка розвідок І.Качуровського [5, 6], який також був перекладачем із кількох мов. У своїй однойменній статті про перекладачів української діаспори критик датує початок перекладознавства в українському зарубіжжі 1946 роком. Ця дата пов'язана з часом виходу в Німеччині першого номеру журналу «Хорс», редактором якого був Ігор Костецький [5, с.565]. Випуск містив оригінальні твори письменників-емігрантів - Василя Барки, Віктора Домонтовича, Юрія Клена, Ю. Косача, Є. Маланюка, Т. Осьмачки та ін. А поряд - переклади з Ф. Гельдерліна, Ф. Петрарки, Ф.Г.Лорки, Е. Хемінгуея та ін., здійснені Олексою Веретенченком, М. Зеровим, Михайлом Орестом, Сергієм Домазаром. Крім «Хорсу», переклади також виходили в тогочасних еміграційних журналах «Літаври», «Арка» та «Звено». До інших типів публікацій перекладів в українському зарубіжжі згадуваний І. Качуровський відносив збірки поезій певного автора з циклом перекладів, а також видання перекладу окремою книжкою [5, с. 568].

Як твердив I. Качуровський, у часи МУРу було багато передруків із попередніх видань [5, с. 567]. До таких перекладів належали і дитячі книжки. Як це можемо дізнатися зі статті Ю. Тищенка «З історії української дитячої книжки», видавництво «Лан», яке спеціалізувалося на перекладній дитячій літературі, за роки своєї діяльності видало сімнадцять книг, з-поміж яких твори Р. Кіплінга та В.Гауфа в перекладах самого Ю. Тищенка-Сірого, а також О. Олеся [13]. Згодом ці та інші переклади дитячих творів публікувалися повторно в журналах або виходили окремими книгами, про що ведемо мову в іншій своїй публікації [1].

Засадничі положення, які формували і перекладацьку лінію часів МУРу, висвітлені у програмовій статті «Велика література» У. Самчука. Як наголосив М. Ільницький, вони визначалися двома головними тезами: (1) через начіональне література досягае рівня загальнолюдсъкого, адже Шекспір $i$ Гете були національними писъменниками, але належать усъому людству; (2) українсъка начія мае репрезентувати себе перед світом як духовна, культурна одинии,я [4, с. 112]. Тож головним здобутком цього часу, можна вважати не лише активізацію перекладацької діяльності українців зарубіжжя, а й осмислення перекладу як необхідної складової популяризації української мови та культури. 
20 Літератури світу: поетика, ментальність і духовність. 2020. Bип.14

Водночас актуальним для часів МУРу було питання браку якісної перекладної літератури з української мови. Про це йшлося у знаковій статті «Українська еміграційна література в Европі 1945-1949» Ю. Шевельова, який писав: «..видання поза чужинец,кими видавництвами майже не досягають своєї мети. Вони не потрапляють у мережу кольпортажу даної краӥни, не пробивають дороги до критичних органів, а якщо кудись $i$ потрапляють, то зустрічаються там з недовір'ям, як усяке самовидання» [14, с. 678]. Критик пов'язує із цим періодом вихід лише кількох книг наукового та художнього спрямування: німецькою мовою - I. Костецького Sechs Leuchter und der Siebente der Mond, Яра Славутича Spiegel und Erneuerung, В. Державина Gelb und Blau, Ю. Шереха Ein neues Theater?, а також французькою - В. Винниченка «Нова Заповідь» (Nouveau Commandement).

Цей перелік значно розширений у двотомній праці «Українська еміграція в Німеччині і Австрії по Другій світовій війні» дослідника українського закордоння В. Маруняка $[10,11]$. Видавничу діяльність у 1945-1951 роках він поділяе на два етапи за кількістю видань та рівнем їх перекладів як іноземними мовами, так і українською. Крім уже названих перекладів з переліку Ю. Шевельова, повоєнні німецькі переклади з української мови представлені книгою Ю. Косача Abend bei Royumovsky тощо. Українською мовою перекладалися також тексти про підручники для середньої школи [10, с. 224].

Видавничий процес 1952-1975 pр. української еміграції в Німеччині й Австрії В. Маруняк аналізує крізь призму діяльності трьох головних видавництв - «Інституту літератури імені М. Ореста», видавництв «На горі» та «Сучасність». Цей етап науковець називає початком «фази публікацій перекладної літератури», що пов'язано з переселенням української інтелігенції за океан та відповідно браком оригінальної літератури: «Перекладну і самовидавсъку літературу слід вважати характерною рисою літературного періоду 1952-1975 рр., бо ані перед тим, ані після того не публіковано було стілъки перекладів з європейсъких $i$ позаєвропейсъких літератур, як в тих роках» [11, c. 41]. Загалом у цей період видано тридцять три книги перекладів (з англійської, німецької, французької, іспанської, китайської, японської та польської), а також двадцять книг з української на німецьку [11, с. 44].

Як один зі співвласників згадуваного вище видавництва «На горі», I. Костецький опублікував значну кількість перекладів, серед яких твори Т. С. Еліота, О. Вайлда, Г. Лорки, Т. С. Еліота, П. Верлена та ін. Властиво, що їх вибір відбивав світогляд самого видавця та перекладача. 
Як слушно зауважила С. Павличко, «перекладащтво для Костецького стало на ией час головним способом модернізувати культуру. Тому завдання полягало не в тому, шоб перекласти класику, тим більше не фольклорні пам'ятники: йшлося про твори сучасні в сенсі їхньой модерності» [12, с.353]. Тяжіння до модерного - стало однієї 3 прикмет того часу, зокрема для «молодшого покоління» перекладачів українського зарубіжжя.

Схожу ідею про розвиток мистецького перекладу та його значення для української діаспори продовжував Г. Костюк у своїх публікаціях «На магістралях історї̈ й «3 літопису літературного життя в діаспорі» [8], де критика цікавить перекладацька діяльність представників Об'єднання українських письменників в екзилі «Слово» (засноване 1954 році у Нью-Йорку, голова - Г. Костюк), зокрема і «нью-йоркської групи». У цих статтях дослідник зафіксував збільшення мов та творів, до яких зверталися українські перекладачі того часу, а вибір перекладу пояснював тим, що це відбивало світогляд та особистість самого перекладача. Крім англійської, німецької та французької, перекладалися твори такими мовами як іспанська, португальська, китайська, японська тощо.

Проте головним досягненням цього часу стало збільшення, порівняно з періодом МУРу, перекладів українських творів різними мовами, чим значно збагатилася теорія і практика художнього перекладу. Це - прозові твори Івана Багряного («Тигролови»), Тодося Осьмачки («Ротонда душогубців»), поезії Яра Славутича, Є. Маланюка, Василя Барки, Віри Вовк та ін., антологї української класичної й сучасної прози тощо, що виходили англійською, німецькою, нідерландською, французькою, португальською. У цей час вийшла антологія перекладів п'ятдесятьма мовами світу із «Заповіту» Т. Шевченка.

За слушним спостереженням Г. Костюка, «..оригінальні й перекладні зусилля писъменників українсъкого закордоння творять поза межами України той літературний фонд, який за законами (...) соціалъного електромагнітного поля істотно доповнюе $i$ збагачуе украӥнсъку сучасну літературу й допомагае влучити iï в загальнолюдський творчий контекст» [8, с. 84]. Одним із головних здобутків доби «Слова», за критиком, стала творчість молодшої групи письменників українського закордоння «нью-йоркської групи», які не лише збагатили українську літературу оригінальними поезіями з високим рівнем інтелектуалізму й філософічності, а й активно працювали на ниві художнього перекладу. До таких митців- 
перекладачів Г. Костюк зараховував Остапа Тарнавського, осмислюючи його перекладацькі зацікавлення (Р. М. Рільке, Г. Гессе, Т. Е. Павнд та ін.) та творчу манеру власних, оригінальних, поезій [8, с. 200].

Окремо розвивалася перекладна дитяча література. Тут активно співпрацювало зі «Словом» інше угруповання української діаспори Об'єднання працівників дитячої літератури імені Л. Глібова (ОПДЛ), що відновило свою діяльність у Нью-Йорку 1951 року, а в 1954 році продовжувало своє функціонування в Торонто як Об'єднання «Українські працівники літератури для дітей і молоді ім. Л. Глібова». Один із ідеологів організації Б. Гошовський у своїй головній праці «Українська дитяча література: спроба огляду і проблематика» визначив активних перекладачів дитячої літератури з української на англійську, німецьку чи французьку та навпаки, серед яких Л. Бризгун-Шанта, Л. Горбач, М. Галун-Блок, Ї. Шугай, В. Шалі, С. Наумович та ін. Попри певні досягнення чимало творів для дітей та юнацтва не були перекладені, натомість з'являлися білінгвальні (двомовні) книги переважно класиків літератури, що віддзеркалювало тогочасні процеси українського зарубіжжя.

Другий напрямок перекладацької діяльності української діаспори розкриває питання теоретичних аспектів перекладу, загальної теорії перекладу, зокрема і його виду - художнього перекладу. Так, Б. Кравців у вище аналізованій статті дає означення дефініції «перекладної літератури», під якою розуміє «рід літературної творчості, в процесі якоӥ літературні твори однієї мови відтворюються засобами іншої мови з більшим чи меншим наближенням до оригіналу у змісті й формі» [7, с. 1987]. До цієі літератури дослідник зараховує вільні переклади, перекази та переспіви. А «мистецький переклад» означив як окрему ділянку літературознавства [7, с. 1987].

Переклад як чинник становлення літератури осмислювався у праці І. Костецького «Український реалізм XX століття» (збірник МУР, 1937 р.), у якій автор розглядає два поняття: «поняття українсъкості $i$ поняття реалістичності съогоднішнъого нашого красного писъменства». Аналізуючи цю публікацію, М. Ільницький звертає увагу на те, що перше поняття підводить I. Костецького до висновку, що першотвір е основою для творення його нового варіанта в іншій мовній системі; друге - до того, що секрет національної творчості полягае не у виборі сюжету, а в його трактуванні (як приклад, наводиться творчість К. Чапека і У. Шекспіра, В. Стефаника і Лесі Українки) [4, с. 122]. 
Вагоме місце в теоретичних студіях займало питання перекладу поезій. Такій проблематиці присвячена стаття Б.Лепкого «До питання про переклади ліричних поезій». У ній автор зачіпає поняття «адекватності» та «вірності» перекладу, відтворення ритміки та індивідуальності автора першотвору. У цьому контексті важливими $€$ його поради щодо дотримання еквівалентності під час перекладу поетичних текстів, серед них: «1) Перекладати лиш з оригіналу $i$ тільки тоді, коли знаємо мову оригіналу не менше, від мови перекладу. 2) Вибирати твори, що нам особливо подобаються $i$ таких авторів, які нам промовляють до душі, бо перекладач мусить відчути автора, перенятися його способом думання $i$ писання, його темпераментом, мусить ототожнюватися з ним, а про себе забути. 3) Не перекладати, поки не проаналізуємо твору, не збагнемо його ритміки, строфіки, евфоніки, його римів, порівнянъ, динаміки слова, орнаментики i всіх своєрідних його прикмет. . .» [9, с. 171-172].

Проблеми тлумачення поетичного тексту були в центрі уваги I. Качуровського. Сам критик добре знався на античній літературі та захоплювався їі системою віршування. За адекватність перекладу античної спадщини I. Качуровський найбільше цінував неокласиків, зокрема М. Зерова. Проте не оминув увагою художні переклади таких українських (радянських) перекладачів як Борис Тен та Андрій Содомора. Він зараховував Бориса Тена до класиків українського перекладацтва та високо оцінював його переклади «Іліади», «Одіссеї» Гомера, Есхіла, Аристотеля, Софокла, Евріпіда та ін. Розглядаючи перекладацьку майстерність Бориса Тена, дослідник простежує два шляхи українського перекладацтва у відтворенні античної літератури. Перший шлях він пов'язує з традицією Степана Руданського. Цей шлях І. Качуровський назвав шляхом нострифікації Гомера. Дослідник підсумовує: «Tут прикро вражає відмова перекладачів од гекзаметра, ніби невластивого українсъкій поезї̈» [6, с. 17]. Другий шлях, за критиком, «ие збагачення українсъкої культури здобутками старогрецької поезії, рецепція метричних і стилістичних засобів» [6, с. 17]. Такі інтенції втілено і в розвідці про «Метаморфози» Овідія в перекладі А. Содомори. Критик високо оцінює його мистецький рівень, якому протиставляє буквалізм у перекладі, називаючи це «горезвісною традицією травестованого й нострифікованого перекладу» [6, с.50].

I. Качуровський не лише детально досліджував поетичний переклад (віршування, відтворення ритміки тощо). У колі його зацікавлень було вивчення принципів укладання перекладних антологій. В одній із таких рецензій на антологію «Співець» за упорядкуванням Г. Кочура 
дослідник не лише аналізує підбірку перекладів західноєвропейський поезї доби романтизму, а й розмірковує про способи ознайомлення 3 літературою іноземною мовою: безпосередньо (хто знає мову), шляхом перекладів рідною мовою та за посередництвом перекладу іншою мовою. Для ученого, саме уникання посередництва дає можливість відкрити світ поезії в перекладі.

Варто наголосити, що зазвичай перекладачі українського зарубіжжя були переважно теоретиками та критиками художнього перекладу. Це визначало напрямок українського перекладацтва в зарубіжжі. Тож, узагальнюючи перекладну діяльність в українському зарубіжжі, I. Костецький визначає дві їі течї: школу $M$. Зерова, до якої зараховував Юрія Клена, Михайла Ореста, Яра Славутича, С. Гординського, I. Качуровського, О. Зуєвського; школу «нъю-йорсъкої групи», яка, на думку дослідника, «орієнтується на теорію й практику сучасного західного перекладацтва, відтворюючи лише зміст та ігноруючи такі явища, як рима i розмір» [5, с. 578]. Такі спостереження дають змогу простежити формування українського перекладознавства з його традиціями та новаціями як цілісного явища.

Тим самим, третій напрямок охоплює власне мистецькі практики перекладачів українського зарубіжжя. Осмислення таких художніх практик - справа не однієї статті. Адже українське перекладацтво презентовано цілою низкою постатей перекладачів. Згадки про них містять аналізовані в цій статті публікації дослідників українського зарубіжжя Б. Гошовського, Б. Кравціва, І. Качуровського, Г. Костюка, В. Маруняка, Г. Шевельова та ін.

У розвідках дослідників упорядкування переліку перекладачів української діаспори здійснюється за такими критеріями: мови здійснених перекладів (англійська, німецька, португальська, іспанська тощо), родо-жанровий (проза, поезї, драматургія, переклади літератури для дітей), хронологічний (період міжвоєння, МУР, «Слово»), за приналежністю до певної перекладацької школи («школа неокласиків» / «нью-йоркська група») або покоління («старше покоління» / «поколінні Другої світової війни» / «молодше покоління»), чи, як в І. Качуровського, «місия, яке займає перекладацтво в їхній mворчості» [5, с.578], за чим вони поділялися на перекладачів професійних та відповідно перекладачів принагідних. Кожна з цих класифікацій є умовною, але для історї українського перекладу, на наш погляд, науковий інтерес може становити критерій хронологічний або приналежності до школи чи покоління, що дасть змогу простежити еволюцію перекладацтва в українському зарубіжжі. Але водночас, 
художній переклад окремо взятого перекладача є способом осмислення різних важливих літературних питань перекладу: 3 практичною метою - засвоєння досвіду, відкриття особистості перекладача та актуальної для української діаспори ідеї націотворення.

Висновки та перспективи подальших пошуків. Ця розвідка не претендує на всеохопність. У ній увага зосереджена на узагальненні кількох напрямків перекладацької діяльності української діаспори, осмислення яких потребує більш детального дослідження.

Увага до окремих постатей українських перекладачів діаспори, осмислення їх теоретичних здобутків на ниві перекладу або ж у порівняльному ключі з українськими перекладачами материкової України, розкриття образів-іміджів України в літературах іноземними мовами української діаспори та націотворчої ролі перекладу - усе це вважаємо за перспективні напрямки майбутніх студій.

\section{Література}

1. Варданян М. В. Ментальний світ українця в перекладній літературі для дітей та юнацтва письменників української діаспори // Наукові праці Кам'янець-Подільського національного університету імені Івана Огієнка. Філологічні науки. Кам'янець-Подільський: Аксіома, 2018. Вип. 46. С. 12-16.

2. Дзюба I. На трьох континентах: у 3-х кн. Київ: Видавництво «КЛІО», 2013. Кн. I: «Нашого цвіту по всьому світу...». Від Малоросії до України. Енциклопедія опору. 807 с.

3. Зарубіжні українці / С. Ю. Лазебник та ін. Київ : Вид-во «Україна», 1991. $252 \mathrm{c}$.

4. Ільницький М. Знаки доби і грані таланту. Київ : ТОВ «Видавництво КЛІО», 2014. 432 с.

5. Качуровський I. Променисті сильветки: лекції, доповіді, статті, есеї, розвідки. Київ : Вид. дім «Києво-Могилянська академія», 2008. $766 \mathrm{c.}$

6. Качуровський I. 150 вікон у світ: з бесід, трансльованих по Радіо «Свобода». Київ : Вид. дім «Києво-Могилянська академія», 2008. $462 \mathrm{c}$.

7. Кравців Б., Жуковський А. Перекладна література // Енциклопедія українознавства. Словникова частина ; гол. ред. В. Кубійович. Париж - Нью-Йорк, 1966. Т. 5. С. 1987-1990. 
26 Літератури світу: поетика, ментальність і духовність. 2020. Bип.14

8. Костюк Г. Вибрані праці: у 5 т. Київ: Смолоскип, 2015. Т. 1: Літературознавство. Критика. 974 с.

9. Лепкий Б. До питання про переклади ліричних поезій // Тетради и практика переводчика. Київ : Вища школа. Вип. 17. 1991. С. 161-172.

10. Маруняк В. Українська еміграція в Німеччині і Австрії по Другій світовій війні. 1945-1951. Мюнхен : Академічне видавництво доктора Петра Белея, 1985. Том I. 435 с.

11. Маруняк В. Українська еміграція в Німеччині і Австрії по Другій світовій війні. 1952-1975. Київ : Видавництво імені Олени Теліги, 1998. Том II. 128 c.

12. Павличко С. Теорія літератури / передм. Марії Зубрицької. Київ : Видавництво Соломії Павличко «Основи», 2002. 697 с.

13. Тищенко Ю. 3 історії української дитячої книги // На сторожі душі української дитини. Париж - Нью-Йорк - Торонто - БуеносАйрос - Мельборн : ОПДЛ, 1951. С. 5-21.

14. Шевельов Ю. Вибрані праці: у 2-х кн. Київ : Вид. дім «КиєвоМогилянська академія», 2009. Кн. ІІ: Літературознавство. 1151 с. 